\title{
GENETIC DIVERGENCE IN ETHIOPIAN CORIANDERACCESSIONS AND ITS IMPLICATION IN BREEDING OF DESIRED PLANT TYPES
}

\author{
BEEMNET MENGESHA, GETINET ALEMAW ${ }^{1}$ and BIZUAYEHU TESFAYE ${ }^{2}$ \\ Wondo Genet Agricultural Research Centre, P. O. Box 198, Shashemene, Ethiopia \\ ${ }^{1}$ Melkasa Agricultural Research Centre, P. O. Box 436 Nazareth, Ethiopia \\ ${ }^{2}$ Hawassa University, P. O.Box 5, Awassa, Ethiopia \\ Corresponding author: mengeshabeemnet@yahoo.com
}

Received 21 August, 2010; accepted 15 February, 2011)

\begin{abstract}
The genetic divergence among 49 Ethiopian coriander (Coriandrum sativum L.) accessions was assessed using employing Mahalanobi's distance (D2) analysis based on 15 characters. The accessions were grouped in to eight clusters. Cluster II and III were the largest each with 12 accessions, followed by clusters I and V each consisting of seven accessions. The highest inter-cluster distance (480.5) was observed between clusters I and VIII, followed by clusters V and VIII (462.2), and then clusters II and VIII (336.1). Hence, crossing between accessions included in these clusters may give high heterotic response, and thereby better sergeants. Maximum contribution toward total genetic divergence was possessed by thousand seed weight (15.67\%), followed by basal leaf number (13.48\%), plant height (10.29\%), seeds umbellet-1 (9.81\%) and umbel number plant-1 (7.84\%). Based on means of all characters, accessions in clusters III, VII and VIII could be regarded as useful sources of genes for yield and its components, and the accessions from these clusters, therefore, could be used in improvement programmes to develop desirable types in coriander.
\end{abstract}

Key Words: Coriandrum sativum, cluster, quantitative characters

\section{RÉSUMÉ}

La divergence génétique parmi 49 accessions de coriandre éthiopienne (Coriandrum sativum L.) était évaluée utlisant l'analyse de la distance de Mahalanobi (D2) basée sur 15 caractères. Les accessions étaient groupées en huit clusters. Les clusters II et III étaient les plus larges avec 12 accessions chacun, suivi des clusters I et V avec sept accessions chacun. La distance la plus élevée entre les clusters (480.5) était observée entre les clusters I et VIII, suivi par les clusters V et VIII (462.2) et enfin les clusters II et VIII (336.1). Ainsi, le croisement entre accessions de ces clusters pourrait offrir une réponse hétérotique élevée et par là de meilleurs ségrégants. Une contribution maximale sur la divergence génétique totale était due au poids de mille grains (15.67\%), suivi par le nombre de feuilles basales (13.48\%), la hauteur de plants (10.29\%), grains par inflorescence (9.81\%) et le nombre d'inflorescences par plant (7.84\%). Basé sur les moyennes de tous les caractères, les accessions des clusters III, IV et VIII pourraient être considérées comme de sources importantes de gènes pour le rendement et ses composantes, et les accessions de ces clusters, pourraient parconséquent être utilisées dans de programmes d'amélioration pour développer de types désirables dans le coriander.

Mot Clés: Coriandrum sativum, cluster, caractère quantitatif 


\section{INTRODUCTION}

Due to wide range of climatic, ecological and topographic conditions, Ethiopia has long been known as a centre of origin and diversity for several plants. From several plant species, coriander (Coriandrum sativum L.) is the one in which Ethiopia is known as a centre of primary diversity (Jansen, 1981). The existence of sufficient variability for agronomic and chemical traits for Ethiopian coriander accessions was also reported by Beemnet and Getinet (2010). Coriander is an annual spice and aromatic herb that belongs to the family umbelliferae/Apiaceae (Hedburg and Hedburg, 2003). It is used in culinary (Diederichsen, 1996), medicine (Kubo et al., 2004; Delaquis et al., 2002) and; its green foliage rich in vitamins and other minerals is used in vegetables and salads. Seeds can be used as a spice and contain essential oils rich in linalool (Singh et al., 2005).

Despite the existence of sufficient variability, market availability and diverse uses, the current knowledge about its biology, variety development and agronomy are neither complete nor conclusive under Ethiopian conditions. This lack of information is a major hindrance to exploit the wealth of coriander diversity in Ethiopia. Thus, initiating a breeding programme, with this economically very important but neglected or under utilised aromatic spice herb contributes a magnificent role for its diversity maintenance, conservation, collection, improvement, cultivation and utilisation.

When initiating a breeding programme with any crop having genetic variation, it is important to gather information on the traits of agronomic importance (Dubley and Moll, 1969). Success in hybridisation and subsequent selection of desirable sergeants depends largely on the selection of parents with high genetic variability for different characters (Sabesan et al., 2009). Neverthless, information concentrating only genetic variability can not be successfully used for discriminating between parents with out knowledge of genetic divergence (Singh et al., 2006).

Genetic divergence is an important factor in any crop improvement programme for obtaining high yielding variety (Rhman and Munsur, 2009).
Selection of parents based on genetic divergence is a pre-requisite in a hetrosis breeding programme (Subrahmanyam et al., 2003). Likewise, Marker and Krupakar (2009) stated that assessment of genetic divergence is an essential pre-requisite for identifying potential parents for hybridisation. Thus, precise information on the nature and degree of genetic divergence helps plant breeders in choosing the diverse parents for purposeful hybridisation. Knowledge on genetic divergence is, therefore, fundamental to identify and organise the available genetic resources aiming at the production of promising cultivars (Palomino et al., 2005).

Genetic divergence can be determined by multivariate analysis, a procedure that is widely used in different crops for parent selection (Cruz et al., 2004a). Multivariate analysis by means of Mahalanobis (1936) D² cluster analysis has been proved to be useful in selecting accessions for hybridisation in several crops. It is powerful tool in quantifying the degree of genetic divergence among parents (Cheema et al., 2004; Bisht et al., 2007; Chaundary et al., 2010).

Although this technique has been used frequently in many crop species, published work on Ethiopian coriander is scanty. Thus, this study was carried out to ascertain the value and magnitude of genetic divergence among 49 Ethiopian coriander accessions from morphological and agronomic variables that might guide the choice of parents for future crossings in breeding programmes in coriander.

\section{MATERIALS AND METHODS}

Description of the research area. The experiment was conducted in two locations of Southern Ethiopia at Kokate and Wondo Genet during the main cropping season of 2007-2008. Kokate is located at $6^{\circ} 532 \mathrm{~N}$ latitude and $37^{\circ} 522 \mathrm{E}$ longitude, with an altitude of 2100 m.a.s.l. It has a humid climate with a mean annual temperature of $18^{\circ} \mathrm{C}$, and mean annual precipitation of about $1300 \mathrm{~mm}$. The soil is sandy loam with a $\mathrm{pH}$ of 4.81 . Wondo Genet is located at $7^{\circ} 192 \mathrm{~N}$ latitude and $38^{\circ} 382 \mathrm{E}$ longitude, with an altitude of 1780 m.a.s.l. The site receives mean annual rainfall of $1000 \mathrm{~mm}$ with respective maximum and minimum temperature of 
10 and $30^{\circ} \mathrm{C}$. The soil is sandy clay loam with an average $\mathrm{pH}$ of 7.2.

Treatments and design. The experiment included 49 accessions (Table 1 ) which were maintained at Wondo Genet Agricultural Research Centre. The experiment was laid out in a randomised complete block design and each accession was replicated two times. The respective spacing between rows and plants were $40 \mathrm{~cm}$ and $30 \mathrm{~cm}$. Plot size was $3.6 \mathrm{~m}^{2}$ with 6 rows having $6 \mathrm{~m}$ length.

Crop management and data collection. Seeds were directly drilled in rows on the prepared experimental units on July 15, 2007 at Kokate, and on July 18, 2007 at Wondo Genet. The experiment was conducted under rain-fed condition. Two hoeing and three weddings were carried out and no fertiliser or chemicals were applied. Samples were taken from the middle three rows of a plot by leaving the two outer rows as border. Five plants were considered for characters measured on individual plant basis. The whole plant was harvested when $50 \%$ of the plants on a plot turn brown. Harvesting was carried out early in the morning and late in the afternoon in order to minimise the fruit losses due to shattering. Then, the whole plant was sun dried for some days and then threshed. The seeds were separated from the plant debris properly for the necessary measurements.

A total of 15 quantitative characters were recorded according to the descriptors of International Plant Genetic Resource Institute (IPGRI) as given by Diederichsen (1996). These are basal leaf number, longest basal leaf length, plant height at full maturity, days to start 50\% flowering, days to end $50 \%$ flowering, days to $50 \%$ maturity, umbel number plant ${ }^{-1}$, thousand seed weight, umbellet number plant ${ }^{-1}$, seed number umbellets ${ }^{-1}$, seed number plant ${ }^{-1}$, seed yield plant ${ }^{-1}$, seed yield, essential oil content and fatty oil content.

Essential oil and fatty oil content analysis. Essential oil content was determined on volume by dry weight (v/w) basis from 50-100 g sun-dried composite seeds from three middle row plants of each plot. Essential oil was produced by hydrodistillation as illustrated by Guenthere (1972).
Fatty oil content was determined from an ovendried $22 \mathrm{~g}$ composite seed samples taken from the three middle rows of each plot by subjecting in to the Nuclear Magnetic Resonance Spectrometer reader (NMRS).

Cluster analysis. Recorded descriptors were subjected to cluster analysis to determine common patterns of variation among groups of accessions. Genetic divergences between clusters were calculated using the generalised Mahalanobi's D² statistics (1936) and clustering of accessions was done according to Tocher's method as described by Rao (1952). SAS computer programme (SAS, 2001) was employed for the analysis following the procedures of average linkage clustering analysis method.

\section{RESULTS AND DISCUSSION}

The 49 accessions of Ethiopian coriander were grouped in to eight clusters based on 15 characters (Table 1 and Fig. 1). The random distribution of the accessions was evident from different clusters. Cluster II and III were the largest, having 12 accessions each indicating the overall genetic similarity among them, cluster I and $\mathrm{V}$ consisted seven accessions each, cluster VI consisted six, cluster IV consisted three and the remaining clusters (VII and VIII) had only one accession each. This is in agreement with Singh et al. (2005) grouping pattern which did not show relationships between genetic divergence and geographical diversity.

Likewise, Sirohi and Dar (2009) reported that changing of genetic material, genetic drift, natural variation and artificial selection other than ecological and geographical diversifications are the causes of genetic divergence. Hence, the accessions were diversified in different agroecologies of Ethiopia. Therefore, intensive collection focusing on the desired traits will benefit breeders by large for effective improvement in coriander.

The intra- and inter-cluster distances $\left(\mathrm{D}^{2}\right)$ values are presented in Table 2. The intra-cluster distance is lower than the inter-cluster distances. Thus, the accessions included with in a cluster had less diversity among themselves. The highest intra-cluster $\mathrm{D}^{2}(0.59)$ was observed in 
TABLE 1. Clustering pattern of 49 Ethiopian coriander accessions on the basis of 15 quantitative characters

\begin{tabular}{lcl}
\hline Cluster & $\begin{array}{c}\text { Number of } \\
\text { accessions }\end{array}$ & \multicolumn{1}{c}{ Accessions } \\
\hline I & 7 & $207517,207518,223114,223289,90311,207516$ and 208026 \\
II & 12 & $211503,219806,223068,240554,240557,240804,242243,242245,212832,207515$, \\
& & 240573,240569 \\
III & 12 & $211471,240563,207519,207520,211473,240568,230495,235787,240564,240805$, \\
& & 240570,222444 \\
N & 3 & $229711,230576,205149$ \\
V & 7 & $203068,207974,229712,234051,229713,242330,240565$ \\
V & 6 & $203066,242246,207973,235827,240572,240574$ \\
VII & 1 & 240803 \\
VIII & 1 & 230577 \\
\hline
\end{tabular}

cluster IV, followed by cluster VI (4.2), $\mathrm{V}$ and I (3.89), II and III (2.81). Clusters VII and VIII contained only one accession and, hence, their intra- cluster distance was zero. The intra-cluster distance in this study is relatively lower than the values between 13.8 and 28.25 reported by Singh et al (2005) and Agdew (2006). Hence, intensive selection for agronomically important characters and similarity in parentage might cause narrow genetic diversity, and uniformity between clusters of low intra cluster distances.

The magnitudes of inter-cluster distance $\left(D^{2}\right)$ were generally high and were indicators for the presence of substantial genetic diversity in Ethiopian coriander accessions. The highest inter-cluster $\mathrm{D}^{2}$ (480.5) was observed between clusters I and VIII, followed by cluster V and VIII (462.2) and cluster II and VIII (336.1). This suggests more variability in genetic make up of the accessions included in these clusters. The accessions belonging to the clusters separated by high statistical distance could be used in hybridisation programme for obtaining a wide spectrum of variation among the segregates. The range of inter-cluster $\mathrm{D}^{2}$ values from 15.1 (cluster I and IV) to 480.5 (cluster I and VIII) obtained in the current study were higher than the intercluster distance (13.8 to 91.3) reported by Singh et al. (2005) and comparable to the values (7.67 to 663.93) reported by Wassihun (2007).

The results on the contribution of individual characters toward the expression of total genetic divergence are presented in Table 3 . The percent contribution was the highest from thousand seed weight (15.67 g), followed by basal leaf number (13.48), plant height $(10.29 \mathrm{~cm})$, seeds number umbellets $^{-1}$ (9.81), umbel number plant ${ }^{-1}$ (7.84), fatty oil content (6.37\%), days to $50 \%$ maturity (5.89), days to end $50 \%$ flowering (4.65), longest basal leaf length (), days to start 50\% flowering, seeds plant ${ }^{-1}$ and seed yield ha-1 each contributed (3.92), seed yield plant ${ }^{-1}$ (3.82) and least is contributed by essential oil content (3.31\%).

The present result is in agreement with Sing et al. (2005), who reported plant height, umbels plant $^{-1}$, leaves plant ${ }^{-1}$ and seeds umbellets ${ }^{-1}$ exerted maximum genetic divergence in coriander. The contribution of various characters towards the expression of genetic divergence should be taken in to account as a criterion for selection of parents for crossing programme (Subrahmanyam et al., 2003). Therefore, among the different characters, thousand seed weight, followed by basal leaf number, plant height, seed number/ umbellets and umbel number/plant should be considered as a criterion for selection of parents for crossing programme.

The mean performance of each cluster for all traits is presented in Table 3. Based on cluster means, greater ranges of mean values among the cluster were recorded for different characters. The result is in agreement with Sing et al. (2005) who reported a wide range of variation in different characters of coriander. Cluster 'I' comprised of $12.24 \%$ of the accessions. In general, cluster I was characterised by low mean values for plant height $(70.92 \mathrm{~cm})$, umbel number plant ${ }^{-1}(99)$, seeds plant ${ }^{-1}(865)$, yield plant ${ }^{-1}\left(9.9\right.$ g), yield ha ${ }^{-1}$ 


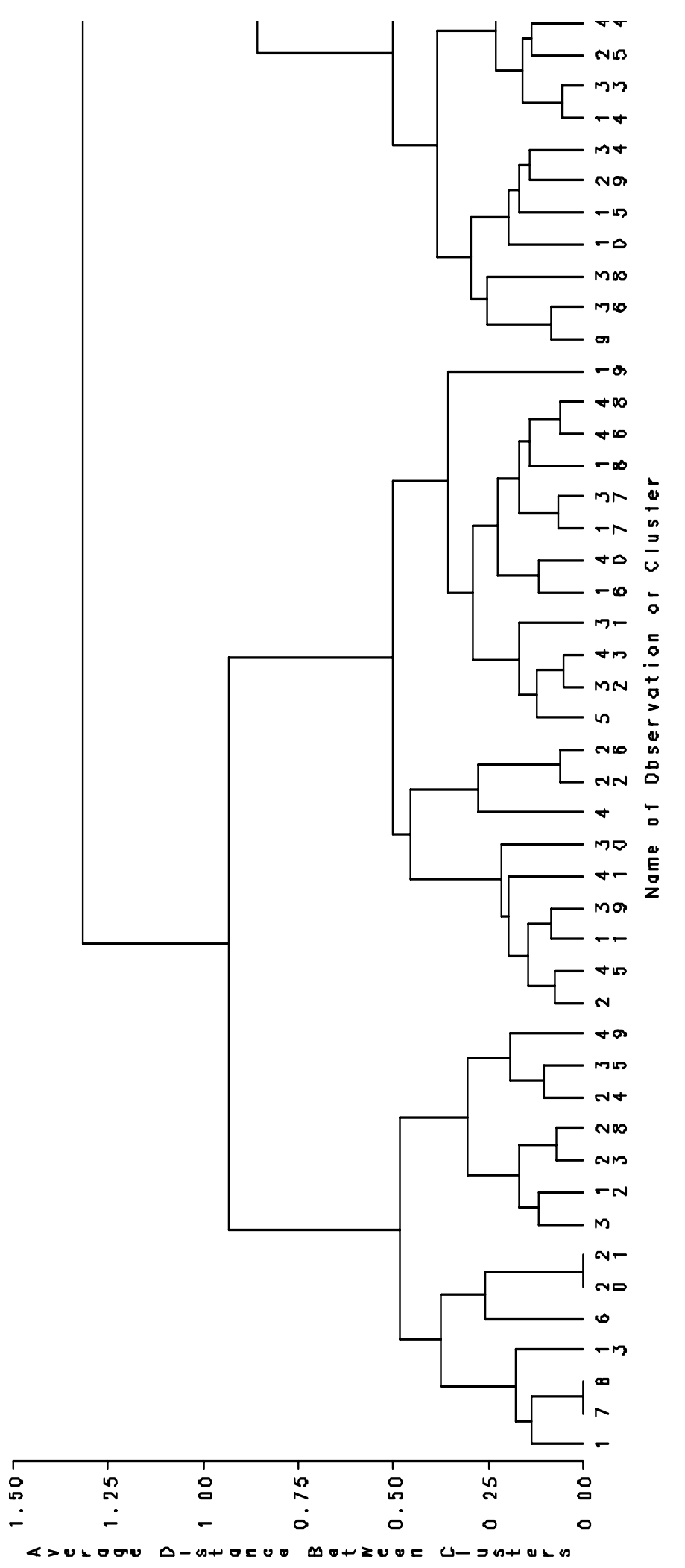

苍灾

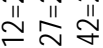

ल

oิ

तi II

0 is

गे ठ

तथ

a

초 궁

तิ त्ञ

$\infty$ ㄱำ

औै के

ㅊำ

$\infty$ ल

究

워ำ

1 ำ

0 o

s.

II $\pi$

की तो

คี

의

แ

के

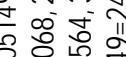

II

of 의 하

80

\& 4

ले त्र

8 我

o 50

근

- तI 4

8 .

क

흔 군

है $\bigcup_{0} \mathrm{~m}_{\mathrm{m}}$ ?

ल

ร

फ

8 过

45

8 \&

정 정

O

용

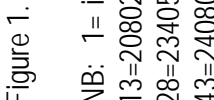


TABLE 2. Intra-cluster (bolded diagonal) and inter-cluster (off diagonal) distance $\left(\mathrm{D}^{2}\right)$ values among 49 Ethiopian coriander accessions on 15 quantitative characters

\begin{tabular}{|c|c|c|c|c|c|c|c|c|}
\hline Cluster & 1 & $\|$ & III & $\mathrm{N}$ & V & $\mathrm{V}$ & $\mathrm{VII}$ & VIII \\
\hline I & 3.89 & $46.31^{\star \star}$ & $179 * \star$ & $95.3^{\star *}$ & 15.1 & $104.4^{\star \star}$ & $262.3^{\star \star}$ & $480.5^{\star \star}$ \\
\hline$\|$ & & 281 & $56.6^{\star \star}$ & 24.3 & $32.6^{\star \star}$ & $25.77^{\star}$ & $117.8^{\star \star}$ & $336.1^{\text {** }}$ \\
\hline III & & & 281 & $26.7^{\star}$ & $138^{\star *}$ & $27.55^{\star}$ & $44.8^{\star \star}$ & $189.6^{* *}$ \\
\hline N & & & & 5.59 & 60 ** & 23.72 & $89.7^{\text {** }}$ & $246.3^{\star \star}$ \\
\hline V & & & & & 3.89 & $87.22^{\star *}$ & $232.4^{\star \star}$ & $426.2^{\text {** }}$ \\
\hline V & & & & & & 4.2 & $47.92^{\star \star}$ & $252^{\star \star}$ \\
\hline VII & & & & & & & 0 & $192.1^{* \star}$ \\
\hline VIII & & & & & & & & 0 \\
\hline
\end{tabular}

$\chi^{2}=25$ and 30.55 at $5 \%$ and $1 \%$ probability level, respectively

(1312.52 kg) and early end flowering (119) and high essential and fatty oil content, which separated this cluster from rests of the clusters.

The accessions of cluster VII had the highest intra- cluster distance. It was separated from other clusters due to its highest mean cluster values for basal leaf number (12), thousand seed weight (11.9 g), umbel number plant ${ }^{-1}$ (147) and seed yield $\mathrm{ha}^{-1}(3099.91 \mathrm{~kg})$ and to its lowest values for umbellets number umbel-1 ${ }^{-1}$ (4.4), number of seeds umbellets $^{-1}(6)$, fatty oil content $(13.75 \%)$ and start flowering early (67). This cluster also showed moderately high inters cluster distance with all the clusters. The cluster 'II' comprised $24.49 \%$ of the genotypes. Distinguished from others due to its accessions with maximum fatty oil content (15.14\%), high essential oil content ( $0.53 \%)$ and start flower lately (82 days) together with seed number/umbellets (6.99). It had low intra cluster distance and also moderately low inters clusters distance with other clusters except with cluster VIII.

Similarly, the clusters 'IV' and 'VIII' were separated with each other and both with other clusters due to containing accessions of long basal leaf $(18.71 \mathrm{~cm})$, late to start flowering (85days), umbellets with highest number of seeds (7) with low essential oil contents ( $0.39 \%$ ) in 'IV'; and shortest $(11 \mathrm{~cm})$ and smallest number of basal leaves (7), earliest to start flowering (61 days), earliest to end flowering (116 days), earliest to mature (129 days), highest number of seeds plant $^{-1}$ (3417.41), and highest seed yield plant ${ }^{-1}$ (32.35 g) in cluster 'VIII'. Both clusters had similar characteristics for thousand seed weight, umbel number plant ${ }^{-1}$; umbellet number umbel ${ }^{-1}$ and fatty oil contents; and also moderately high yielding accessions.

Highest umbellet number umbel ${ }^{-1}$ and thousand seed weight, and had high values for the rest of 13 traits were the characteristic features of accessions in cluster 'III'. It had moderately low inter-cluster distances among other clusters and lowest intra cluster distance.

Cluster ' $V$ ' composed of accessions that were characterised by lightest in thousand seed weight (10.9 g), late to complete flowering (127) and seeds with higher essential (0.55\%). It had moderately low intra- cluster distances with other clusters except its high values with cluster VII and VIII. Accessions categorised in cluster VI were characterised by their tallest plant heights (80.14) and moderately high values for the rest 14 traits. It had moderately high inter-cluster $\mathrm{D}^{2}$ value with VIII and low with the rest of the clusters.

It has been well established fact that more genetically diverse parents used in hybridisation programme, greater will be the chances of obtaining high hetrotic hybrids and broad spectrum variability in segregating generations (Arunachalam, 1981). It has also been reported that the most productive hybrids may come from high yielding parents with high with a high genetic diversity (Marker and Krupakar, 2009). Therefore, based on cluster distances of the present study, accessions included in clusters III and VIII can be utilised as donor parent for improving yield due to their high mean performance for seed yield plant ${ }^{-1}$ and most of the yield contributing traits with good amount of genetic divergence. Though highest inter- cluster distance could be registered between accessions 


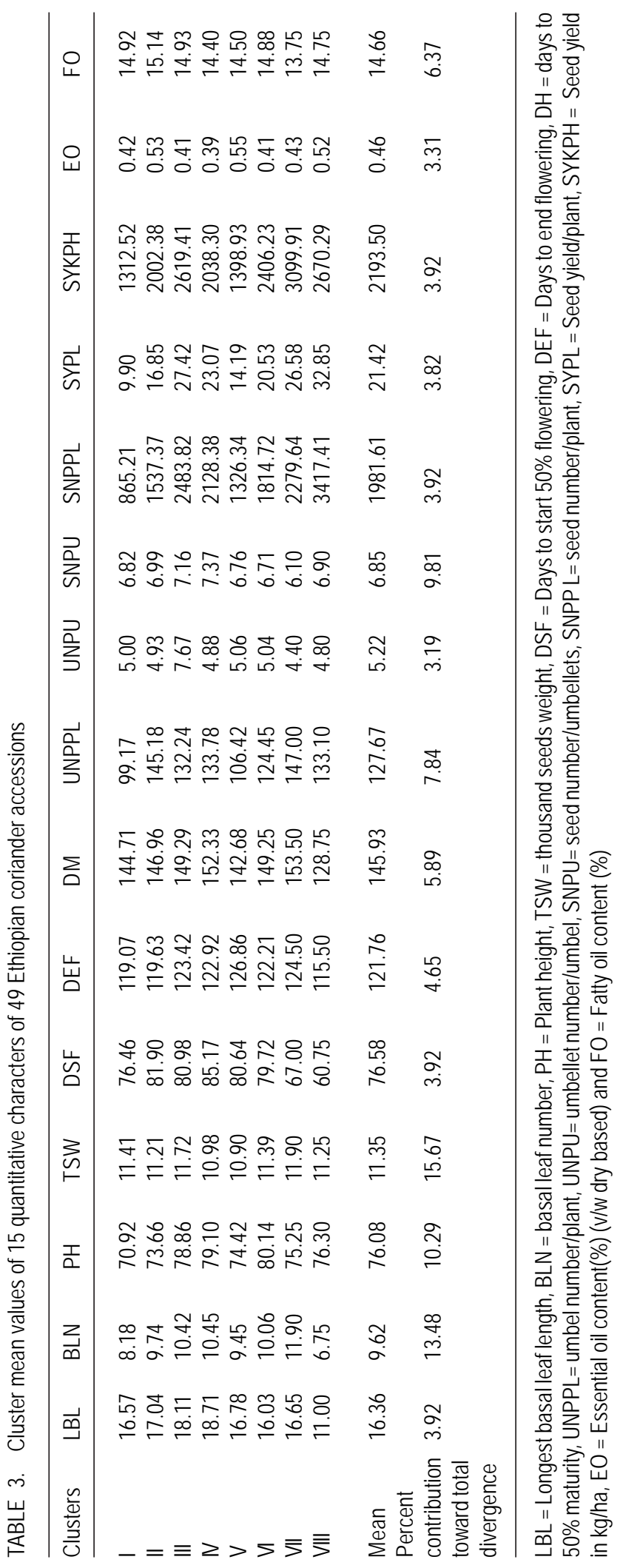


included in clusters I and VIII, the superior derivatives may not be expected from crosses between accessions included in clusters I and VIII due to low mean seed yield performance of cluster I. Moderately high inter cluster distance between V and VII, IV and VIII, and VI and VIII with high mean performance of one or more component traits contributing towards seed yield suggests that some sampled crosses between these clusters may be attempted to select the recombinants for high seed yield. Likewise, crosses between accessions included in clusters II and VIII with high cluster distances with high mean value of essential and fatty oil content in both clusters might be used as a donor parent in breeding programme for high essential and fatty oil content. At the same time, accessions included in clusters VIII might be used as a donor parent in breeding for simultaneous improvement of seed yield, essential and fatty oil content.

\section{ACKNOWLEDGEMENT}

The financial assistance of Canadian International Development Agency (CIDA) and Universities Partnership Cooperation and Development (UPCD) project is sincerely acknowledged. Dr. Hussaien Mohammed, Tewdros Mulualem, Adane Chufere, Fikadu Gurmu and Solomon Admasu are greatly acknowledged for the help in statistical analysis. We thank Zewdnesh Damtew, Shewaye Habte, Solomon Abate, Zerihun Jomba and Taddese Debele for their help in field work and laboratory analysis. Our acknowledgement also goes to Wondo Genet and Holleta Agricultural Research Centres for respective cooperation in essential oil and fatty oil analysis. Equally, we extend our appreciation to Nassa Sabore for his willingness to provide the land for the research work at Kokate.

\section{REFERENCES}

Agedew, B. 2006. Genetic variability and association among yield and yield related traits in soybean (Glycine max L.) at Awassa and Gofa, Southern Ethiopia. M.Sc. Thesis. Alemaya University, Alemaya, Ethiopia. 78pp.
Arunachalam, V. 1981. Genetic distance in plant. Indian Journal of Genetics and Plant Breeding 41:226-236.

Beemnet, M. and Getinet, A. 2010. Variability in Ethiopian coriander accessions for agronomic and quality traits. African Crop Science Journal 18(2):43-49.

Bisht, V., Singh, B., Rao, K.S., Maikhuri, R.K. and Nautiyal, A.R. 2007. Genetic divergence of paddy landraces in Nanakosi microwatershed of Uttarakhand Himalaya. Journal of Tropical Agriculture 45(1-2):48-50.

Chaundary, L., Sindhu, A., Kumar, M., Kumar, R., and Saini, M. 2010. Estimation of genetic divergence among some cotton vaieties by RAPD analysis. Journal of Plant Breeding and Crop Science 2(3):39-43.

Cheema, A.A., Rashid, M., Ashraf, M. and Qamar, Z.U. 2004. Genetic divergence in rice collections. Pakistan Journal of Botany 36(3):557-565.

Cruz, P.J., Carvalho, F.I.F., Oliveira, A.C, Benin, G., Vieira, E.A, Silva, J.A.G., Valerio, I.P., Hartwig, I. and Busato, C.C. 2004. Genetic dissimilarity among wheat genotypes for lodging-associated traits. Crop Breeding and Applied Biotechnology 4:427-433.

Delaquis, P.J., Stanich, K., Girard, B. and Mazza, G. 2002. Antimicrobial activity of individual and mixed fractions of dill, cilantro, coriander and eucalyptus essential oils. International Journal of Food Microbiology 74:101-109.

Diederichsen, A. 1996. Coriander (Corianderum sativum L). Promoting the conservation and use of underutilised and neglected crops. 3. Institute of Plant Genetics and Crop Plant Research, Gaterslbebn/International Plant Genetic Resources Institute, Rome. 83pp.

Dubley, J.W. and Moll, R.H. 1969. Interpretation and use of estimates of heritability and genetic variances in plant breeding. Crop Science 9:257-262.

Hedburg, I. and Hedburg, O. 2003. Flora of Ethiopia and Eritrea Apiaceae to Dipsacaceae. Hedeger, I., S. Edwards and Sileshi Nemomsa (Eds.), Volume 4, Part 1. Uppsala, Sweden. 352pp.

Kubo I., Fujita K., Kubo A., Nihei, K. and Ogura, T. 2004. Antibacterial activity of coriander 
volatile compounds against Salmonella choleraesuis. Journal of Agriculture and Food Chemistry 52(11):3329-3332.

Mahalanobis, P.C. 1936. On the generalised distance in statistics. Proceedings of National Institute of Science (India) 2:49-55.

Marker, S. and Krupakar, A. 2009. Genetic divergence in exotic maize germplasm (Zea mays L.). Journal of Agricultural and Biological Science 4(4):44-47.

Palomino, E.C., Mori, E.S., Zimback, L., Tambarussi, E.V. and Moracs, C.B. 2005. Genetic diversity of common bean genotypes of Carioca commercial group using RADP markers. Crop Breeding and Applied Biotechnology 5: 80-85.

Rao, C.R. 1952. Advance statistical methods in biometrical research. John Wiley and Sons, New York. 390pp.

Rhman, M.M., and Munsur, A.Z.A. 2009. Genetic divergence analysis of lime. Journal of Bangladesh Agricultural University 7(1):3337.

Sabesan, T., Saravanan, K. and Anandan, A. 2009. Genetic divergence analysis for certain yield and quality traits in rice (Oryaza sativa L.) grown in irrigated saline lowland of
Annamalainagar, South India. Journal of Centeral European Agriculture 10(4):405410.

SAS Institute, 2001. SAS software. SAS Institute INC., Cary. NC.USA.

Singh S.P., R.S. Katiyar, S.K. Rai, S.M. Tripayhi, and J.P. Srivastava. 2005. Genetic divergence and its implication in breeding of desired plant type in coriander (Coriandrum sativum L.). Genetika 37(2):155-163.

Singh, P.K, Mishra, M.N., Hore, D.K and Verma, M.R. 2006. Genetic divergence in lowland rice of north eastern region of India. Communications in Biometery and Crop Scinece 1(1):35-40.

Sirohi, S.P.S. and Dar, A.N. 2009. Genetic divergence in soybean (Glycine max L. Mrrill). SKUAST Journal of Research 11(2):200-203.

Subrahmanyam, S.V.R., Kumar, S.S. and Ranganatha, A.R.G. 2003. Genetic divergence for seed parameters in sunflower (Helianthus annuus L.). Helia 26(38):73-80.

Wassihun Legesse. 2006. Agro morphological characterisation of sorghum (Sorghum bicolar L.) landraces from Metekel Zone Benishangul Gumuz region. M.Sc. Thesis. Hawasa University, Awassa, Ethiopia. 102pp. 